\title{
Dig links Stonehenge to circle of life
}

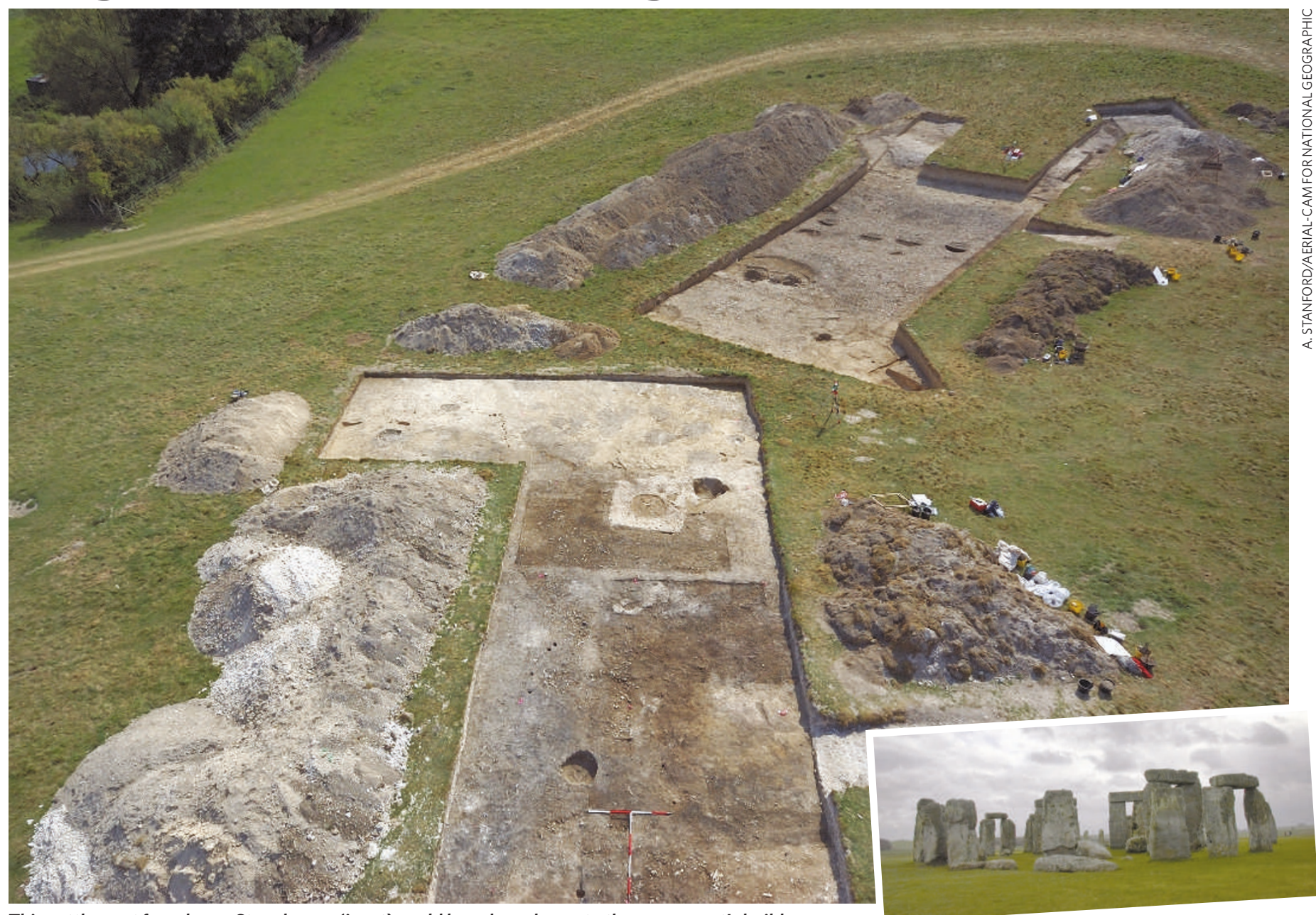

This settlement found near Stonehenge (inset) could have been home to the monument's builders.

When archaeologists announced last week that they had uncovered a major settlement at the site of Stonehenge, you could be forgiven for asking why it hadn't been found before. The legendary circle of standing stones, located in densely populated southern England, is a popular tourist attraction and one of the most famous prehistoric monuments in the world.

But on 30 January, archaeologists reported evidence that Stonehenge is just half of a bigger ceremonial complex. Excavations at a site called Durrington Walls, about three kilometres from Stonehenge, uncovered a cluster of houses and a vast stone avenue that connects the village to what would have been a circular arrangement of huge timber posts.

"There is a kind of complementarity between the timber circle and the stone circle of Stonehenge," says Julian Thomas of the University of Manchester, and a director of the
Stonehenge Riverside Project, which excavated the site last year. Stone avenues connect both circles to the nearby river Avon, but Stonehenge is oriented to face midsummer sunrise and midwinter sunset, whereas the wooden circle would have faced midwinter sunrise and midsummer sunset.

Carbon dating suggests that the structures at Durrington Walls were built around the same time as Stonehenge, in 2600-2500 вС, supporting the idea that the villagers helped to build the stone monument. As well as being the "richest site archaeologically speaking, it's also the filthiest we have ever seen", says project director Mike Parker Pearson of the University of Sheffield, UK. Some 50,000 animal bones found at the site suggest that people went there for "feast and fun". He speculates that the stone and wooden monuments played contrasting roles in cult practices - the wooden one being used to celebrate life, and the stone one to celebrate death.

How did archaeologists miss all this material before? "Because it's a World Heritage Site, there has been a bit of a disincentive for people to go and excavate there," explains Timothy Darvill,
"There is a kind of complementarity between the timber circle and the stone circle of Stonehenge." an archaeologist at Bournemouth University, UK, who was not involved in the latest dig. "In the past, the thrust has been to conserve and protect such areas."

But in recent years, attitudes have been shifting, says Darvill. "People have realized that if you do nothing, you find nothing." That shift in philosophy seems to be paying dividends.

Lucy Odling-Smee

For a more detailed story and an animation of the site, see http://tinyurl.com/2wytlr. 